Journal : JMMR (Jurnal Medicoeticolegal dan Manajemen Rumah Sakit), 10 (1): 63-76, April 2021

Website : http://journal.umy.ac.id/index.php/mrs

DOI $\quad$ : https://doi.org/10.18196/jmmr.v10i1.10376

\title{
Analysis of workforce requirements based on WISN in radiology installation of RSU X
}

\author{
Diaz Farrasizdihar $^{1 *}$, Ermi Girsang ${ }^{2}$, Sri Lestari Ramadhani Nasution ${ }^{3}$ \\ $1{ }^{*}$ Correspondence Author: ermigirsang@unprimdn.ac.id \\ 1,2,3 Master of Public Health at Prima Indonesia University, Medan, Indonesia
}

\section{N D E X I N G \\ Keywords: \\ WISN; \\ Workload; \\ Workforce.}

Kata Kunci:

WISN;

Beban kerja;

Tenaga kerja.

\begin{abstract}
A B S T R AC T
The beginning of 2020 was shocked by the WHO's statement, which mentioned Coronavirus-19 (COVID-19) as a pandemic. The Ministry of Health of the Republic of Indonesia reports 37420 confirmed cases of COVID-19 in June 2020 and are growing every day. One of the supporting examinations to establish a diagnosis of COVID-19 is a radiological examination. It is undeniable that the increasing incidence of COVID-19 has caused health workers' workload in hospitals, including in radiology installations. This study aimed to analyze the workforce's need according to the workload using the Workload indicators of staffing need (WISN) method in the radiology installation of the RSU X. This research uses quantitative and qualitative methods. The results showed that the workforce's workload in the radiology installation at RSU X was optimum. Based on calculations using the WISN method, the total number of workers needed at the radiology installation at the RSU X was 15 people, and the workforce gap ratio was 1,00 .
\end{abstract}

Awal tahun 2020 dikejutkan dengan pernyataan WHO yang menyebut Coronavirus-19 (COVID-19) sebagai pandemi. Kementerian Kesehatan Republik Indonesia melaporkan 37.420 kasus COVID-19 yang dikonfirmasi pada Juni 2020 dan terus bertambah setiap hari. Salah satu pemeriksaan penunjang untuk menegakkan diagnosis COVID-19 adalah pemeriksaan radiologi. Tidak dapat dipungkiri, meningkatnya kejadian COVID-19 telah menyebabkan beban kerja petugas kesehatan di rumah sakit, termasuk di instalasi radiologi. Penelitian ini bertujuan untuk menganalisis kebutuhan tenaga kerja sesuai beban kerja dengan menggunakan metode Workload indicator of staffing need (WISN) di instalasi radiologi RSU X. Penelitian ini menggunakan metode kuantitatif dan kualitatif. Hasil penelitian menunjukkan bahwa beban kerja tenaga kerja di instalasi radiologi RSU X sudah optimal. Berdasarkan perhitungan dengan metode WISN, jumlah tenaga yang dibutuhkan pada instalasi radiologi RSU X sebanyak 15 orang, dan workforce gap ratio sebesar 1,00 .

C) 2021 JMMR. All rights reserved

Article history: Received 2020-11-16; Revised 2020-12-28; Accepted 2021-02-25

\section{INTRODUCTION}

At the beginning of 2020, the world was overwhelmed by the WHO's statement, which mentioned Coronavirus-19 (COVID-19) as a pandemic. Pandemic is a disease that is endemic in many countries globally. The COVID-19 pandemic was spreading rapidly, and people infected with COVID-19 may not show any symptoms. COVID-19 was declared a pandemic by WHO in March 2020 (Xie \& Chen, 2020). COVID-19 first showed in Wuhan City, Hubei Province, China, in December 2019 (Huang et al., 2020). COVID-19 cases in Wuhan and China continued to increase following the discovery of the first cases. COVID-19 is a disease caused by a virus and can also cause death with a case fatality rate of $2 \%$ (Huang et al., 2020).

As of June 2020, COVID-19 has infected 216 countries with confirmed cases globally reported to WHO of 7,553,182 with a death rate of 423,349 . The confirmed cases of COVID-19 reported to WHO is still increasing every day to date. It shows that COVID-19 continues to be a problem in many countries, including Indonesia (World Health Organization, 2020). Indonesia has been reported 37,420 confirmed cases of COVID-19 until June 2020, with a death toll of 2,091. The 
confirmed cases of COVID-19 that reported to the Indonesian Ministry of Health also continue to increase each day (Kementerian Kesehatan Republik Indonesia, 2020).

COVID-19 transmits through droplets that appear when a person infected with COVID-19 coughs or sneezes (Acter et al., 2020). It transmits through the respiratory tract, digestive tract, and mucosal surfaces (for example, the conjunctiva) (Ye et al., 2020). The clinical symptoms in COVID-19 are similar to those of other pneumonia viruses like MERS and SARS. In mild cases, symptoms can disappear on their own and get better within two weeks. Patients with severe symptoms may develop acute respiratory distress syndrome (ARDS), septic shock, and multiple organ failure (Xie \& Chen, 2020). Radiology services are an integrated part of comprehensive health services. With the increasing public need for health services, radiology services should provide quality services (Hasmawati et al., 2018).

One of the supporting examinations to establish a diagnosis of COVID-19 is a radiological examination. The examination includes chest radiographs, chest CT scans, and chest ultrasonography (USG) (PDPI, 2020). The required radiological examination is one of the conditions for returning COVID-19 patients home after undergoing treatment in the hospital (Kementerian Kesehatan RI, 2020). Based on the Decree of the Minister of Health of the Republic of Indonesia Number 1014/Menkes/SK/XI/2008 concerning diagnostic radiology service standards in health service facilities, General Hospital (RSU) of X, which is a class B hospital, should have two radiology specialists, two radiographers/equipment, one medical radiation protection staff, one medical physicist, one electromedical staff, two nurses, three administrative and darkroom staff (Menteri Kesehatan Republik Indonesia, 2008). RSU X should have 18 workforces in the radiology installation with the provisions above. There are four radiology tools at RSU X, including digital radiography, CT scan, mammography, and USG. However, until July 2020, the workforce at the radiology installation at RSU X was 14 people.

Unmet HR needs to have a high workload effect on the workforce (Alam et al., 2018). The workload is one aspect that must be considered by every organization or company because the workload will affect workforces in increasing productivity and feeling comfortable while working (Astuti \& Lesmana, 2018). Undeniably, with the increasing incidence of COVID-19, the workload on health workers in hospitals also increases (Fadli et al., 2020). Workload analysis is a management technique performed systematically to obtain information on work effectiveness and efficiency. It can help determine the ideal number of officers. One method for determining workforce requirements based on workload is the WISN (Workload Indicators of Staffing Needs) method. This method is a form of rationalizing the workforce requirements based on the workforce's workload (Alam et al., 2018). The mismatch in the number of workers in the radiology installation at RSU X can lead to workload problems in the future. This research aims to analyze the workforce requirements so that the number of workers is following the workload.

\section{RESEARCH METHODS}

The method used in this study was mixed methods. In this study, a quantitative method with an observational approach takes work sampling by observing respondents' activity. Productive time indicates the workload category. Furthermore, observations use to analyze workforce requirements using the Workload Indicators of Staffing Need (WISN) method. In-depth interviews with workers performed qualitative methods to strengthen quantitative research results and explore informant responses based on research objectives. The research population was all workers in the radiology installation of RSU X. The selection of this purposive sampling technique shows that the selected sample had sufficient qualifications to represent the population. It is because the representation of the sample is very influential in the research results. The inclusion criteria in selecting the sample include the workforce's activities in radiology installations with a work experience of more than one year, 
workers willing to be research respondents, and currently working hours. During the research, it acquires a sample of 5460 minutes of work activities from 9 workers who were willing to become research respondents.

Table 1. Operational Definition

\begin{tabular}{|c|c|c|c|}
\hline Variable & Operational Definition & $\begin{array}{l}\text { Measuring } \\
\text { instrument }\end{array}$ & Measuring Results \\
\hline Workload & $\begin{array}{l}\text { Activities that calculate the } \\
\text { workload of the workforce by } \\
\text { observing the activities } \\
\text { performed by the workforce }\end{array}$ & $\begin{array}{l}\text { Observation of } \\
\text { activities with the } \\
\text { work sampling } \\
\text { method }\end{array}$ & $\begin{array}{l}\text { In the form of the amount of } \\
\text { workload with scores of heavy, } \\
\text { medium, light (interval) }\end{array}$ \\
\hline $\begin{array}{l}\text { Available } \\
\text { Working } \\
\text { Time }\end{array}$ & $\begin{array}{l}\text { A quantitative figure showing } \\
\text { the unit of time in a year spent } \\
\text { working in minutes }\end{array}$ & $\begin{array}{l}\text { The working time } \\
\text { formula is available } \\
\text { with data obtained } \\
\text { from reviewing the } \\
\text { hospital documents }\end{array}$ & $\begin{array}{l}\text { Quantitative information on the } \\
\text { amount of time in a year a radiology } \\
\text { installation worker works in minutes }\end{array}$ \\
\hline $\begin{array}{l}\text { Standard } \\
\text { Workloads }\end{array}$ & $\begin{array}{l}\text { The number of work (in one } \\
\text { primary service activity) that } \\
\text { can be performed by a health } \\
\text { worker in a year in a radiology } \\
\text { installation }\end{array}$ & $\begin{array}{l}\text { Workload standard } \\
\text { formula with data } \\
\text { obtained from } \\
\text { observations }\end{array}$ & $\begin{array}{l}\text { Volume/quantity of staff workload in } \\
\text { registration counters in a year }\end{array}$ \\
\hline $\begin{array}{l}\text { Allowance } \\
\text { Standards }\end{array}$ & $\begin{array}{l}\text { The amount of time required } \\
\text { by the workforce to perform all } \\
\text { types of activities that are not } \\
\text { directly related or affect the } \\
\text { high or low quality or number } \\
\text { of productive activities of the } \\
\text { radiology installation }\end{array}$ & $\begin{array}{l}\text { Allowance standard } \\
\text { formula with data } \\
\text { obtained from } \\
\text { reviewing } \\
\text { documents and } \\
\text { interviews }\end{array}$ & $\begin{array}{l}\text { The amount of time required by the } \\
\text { workforce at the radiology installation } \\
\text { to perform all types of activities that } \\
\text { are not directly associated with or } \\
\text { affect the high or low quality or the } \\
\text { number of productive activities of the } \\
\text { radiology installation }\end{array}$ \\
\hline $\begin{array}{l}\text { The number } \\
\text { of workforce } \\
\text { requirements }\end{array}$ & $\begin{array}{l}\text { Quantitative number of } \\
\text { workforce requirements } \\
\text { to complete the entire } \\
\text { workload }\end{array}$ & WISN formula & $\begin{array}{l}\text { The number of human resources for } \\
\text { the radiology installation workforce is } \\
\text { following the calculation results }\end{array}$ \\
\hline
\end{tabular}

Source: (Rubbiana, 2015).

\section{General description of RSU X}

\section{RESULT AND DISCUSSION}

RSU X is a class B private hospital with 643 beds available as of December 2017. Radiology installation at RSU X is an installation that performs examination services in diagnostic imaging regarding individual health interests, notably to support disease diagnosis, disease healing, and health recovery. The radiology installation position in RSU X is essential as it follows its function, which helps manage hospital patients. To perform a radiology installation function requires many types of personnel with competencies, various technologies, and tools of examinations ranging from the simplest to the most sophisticated, various types of supplies for all types of examinations. Radiology installation collaborates with various parties that support radiology installation activities, such as nurses, pharmacy, logistics, and radiology equipment distributors. Currently, the radiology installation at RSU X has four radiology tools, including digital radiography, CT scan, ultrasonographyy (USG), and mammography. 


\section{Characteristics of Respondents}

The total workforce at the radiology installation at RSU X in October 2020 was 15 people, with a composition of six men and nine women. Each workforce has different characteristics, seen from education, age, gender, and work length. The workforce in the radiology installation at RSU X is at a productive age level between 21 years - 44 years with different educational backgrounds of 12 or $80 \%$ of D3 graduates, 2 or $13 \%$ of specialist graduates, and the remaining one person or $7 \%$ of master graduate. The respondents' length of work varies from those who have only worked for two months to six years.

\section{Workload analysis based on Work Sampling}

Workload analysis takes to understand the workload illustration of the radiology department of RSU X using observation and enhanced with interview results. As an instrument in observing the workload of the workforce in the radiology unit, researchers use work sampling forms. The activities observed were divided into three groups, i.e., (Fadila, 2019):

a) Primary activities/productive are activities that are related directly to the patient or patient care. Productive activities in radiology unit RSU X include input data from the patient, patient preparation, imaging process, clean up patients and clean up the room, burning picture/print picture, read the results, load results in the system, and deliver the results to the inpatient unit and outpatient unit.

b) Non-Productive Activities are not related to the unit's primary and support activities or function and are not beneficial to the service unit. E.g., playing cell phone, chit-chatting, and so on.

c) Personal Activities are activities related to personal matters and needs, like a drink, eat, pray, and go to the toilet.

The following is a table of results of workload analysis based on work sampling.

Table 2. Workload Analysis based on Work Sampling in Radiology Installation of RSU X

\begin{tabular}{clc}
\hline No. & \multicolumn{1}{c}{ Activities } & Percentage (\%) \\
\hline 1 & Produktive activities & 80 \\
\hline 2 & Non-Produktive activities & 14 \\
\hline 3 & Personal activities & 6 \\
\hline \multicolumn{2}{c}{ Total } & 100 \\
\hline
\end{tabular}

Source: the results of observation activity

Table 2. results from observations of the usage of time for seven days carried out by radiology workers at RSU X. Radiology workers of RSU X mostly use the time to carry out productive activities as much as $80 \%$. Non-productive activities consume as much as $14 \%$ of the time. At the same time, the use of time for personal activities was $6 \%$. From the interview results, it can conclude that with the current pandemic situation, the obstacles and burdens in doing work are more CT scan requests, and CT scan processing time is longer than other imaging operations.

\section{Workforce necessity analysis based on WISN in the radiology unit RSU X Available working hours}

The workforce in the radiology unit of RSU X has to work 40 hours per week as a shift clerk. With the length of work in one day per shift is 8 hours, the workforce in the radiology unit has a working time of 5 days per week. The radiology department workforce of RSU X has 260 working days per year. 
Based on the RSU X policy, workforces at the RSU X have an annual leave of 12 days per year. Workshop and training establish according to each work unit. In the past year, the radiology unit has conducted four workshops and training sessions. According to (Menteri Ketenagakerjaan et al., 2020), national holidays in 2020 are as many as 20 days with a description of 16 national holidays and four days of collective leave.

Available working time formula:

$$
\text { Available working time }=(A-(B+C+D+E)) \times F
$$

explanation:
A: Working days
B: Annual leave
C: workshop and training
D: national holidays
E: Absence of work
F: the number of work hours

Based on the table 3 this formula, the following work time obtained:

Table 3. Available Work Hours in Radiology Installation of RSU X

\begin{tabular}{llcl}
\hline Code & Factors & Amount & Explanation \\
\hline $\mathrm{A}$ & Working days & 260 & days/year \\
\hline $\mathrm{B}$ & Annual leave & 12 & days/year \\
\hline $\mathrm{C}$ & Workshop and training & 4 & days/year \\
\hline $\mathrm{D}$ & National holidays & 20 & days/year \\
\hline $\mathrm{E}$ & Absence of work & 0 & days/year \\
\hline $\mathrm{F}$ & Amount of work hours & 8 & hours/day \\
\hline \multirow{2}{*}{ Available work hours } & & 224 & days/year \\
\cline { 2 - 4 } & & 1792 & hours/year \\
\hline
\end{tabular}

Source: Data from the hospital's documents

Judging from the above calculations, the available working time at the radiology unit at the RSU X is 107520 minutes per year.

\section{Working Unit}

The working unit in the analysis of workforce requirements in this study is the radiology unit at RSU X.

\section{Determine workload standards}

The standard workload is the measurement result of available work time compared to the average time needed to complete each task. The standard workload calculation formula is as follows:

$$
\text { Workload standards }=\frac{\text { available working hours }}{\text { average time per jobs description }}
$$

The results of standard workload calculations based on observations show in the table 4 . 
Table 4. Workload Standards based on Jobs Description in Radiology Installation of RSU X

\begin{tabular}{llcl} 
No. & Jobs description & Amount (minutes) & $\begin{array}{l}\text { Workload } \\
\text { standards }\end{array}$ \\
\hline 1 & Input patient data & 3 & 35840 \\
\hline 2 & Preparation & 10 & 10752 \\
\hline 3 & Imaging process & 8 & 13440 \\
\hline 4 & Tidying up & 10 & 10752 \\
\hline 5 & Burning picture / printing images & 6 & 17920 \\
\hline 6 & Reading the result & 20 & 5376 \\
\hline 7 & Input data to the system & 3 & 35840 \\
\hline 8 & Delivering & 5 & 21504 \\
\hline
\end{tabular}

Source: the results of observation activity

Table 4 shows that the largest proportion of the workload is in the results reading activity, which takes 20 minutes for each process. Based on the interview results, waiting for a consultant's reading is an activity that requires the longest time. It is because doctors do not stand by 24 hours to read the imaging results.

\section{Determine allowance standards}

Allowance time is the time needed to carry out other activities that are not related to the main activity. The allowance standard calculated using the formula:

$$
\text { allowance standards }=\frac{\text { average time per allowace }}{\text { available working hours }}
$$

Based on the results of observations, the allowance standards are as follows.

Table 5. Allowance Standards in Radiology Installation of RSU X

\begin{tabular}{|c|c|c|c|c|c|}
\hline No & Allowance factors & Average time & Hours/year & Minutes/year & $\begin{array}{l}\text { Allowance } \\
\text { standards }\end{array}$ \\
\hline 1 & $\begin{array}{l}\text { Education } \\
\text { training }\end{array}$ & 2 hours/year & 2 & 120 & 0.001 \\
\hline 2 & incidental meetings & 2 years/month & 24 & 1440 & 0.013 \\
\hline 3 & Routine meetings & 1 hour/week & 52 & 3120 & 0.029 \\
\hline 4 & Quarterly reports & 1 hour $/ 3$ months & 4 & 240 & 0.002 \\
\hline 5 & Monthly reports & 1 hour/months & 12 & 720 & 0.007 \\
\hline 6 & Daily reports & 1 hour/day & 365 & 21900 & 0.204 \\
\hline \multicolumn{5}{|c|}{ Allowance standards } & $0.256=0.3$ \\
\hline
\end{tabular}

Source: Data from the hospital's documents $\mathcal{E}$ results of the interview

Table 5. explains that the calculation results show that the proportion of the tolerance for education and training is 0.001 , incidental meetings are 0.013 , routine meetings are 0.029 , quarterly reports are 0.002 , monthly reports are 0.007 , and daily reports are 0.204 . The total standard allowance for the radiology unit is 0.256 or rounded to 0.3 .

\section{Calculation of the number of workforce's requirements}

The formula can obtain a calculation of workforce requirements in the radiology unit of the RSU X using the WISN method: 


$$
\text { workforce requirements }=\frac{\text { quantity of main activities }}{\text { workload standards }}+\text { allowance standards }
$$

The calculation of workforce requirements at the radiology unit of the RSU X shows in the table 6.

Tabel 6. Workforce Requirement based on WISN in Radiology Installation of RSU X

\begin{tabular}{lllll}
\hline No. & Jobs description & $\begin{array}{c}\text { Quantity } \\
\text { activities }\end{array}$ & $\begin{array}{l}\text { of } \\
\text { standards }\end{array}$ & $\begin{array}{l}\text { Workforce } \\
\text { requirements }\end{array}$ \\
\hline 1 & Input patient data & 20192 & 35840 & 0.9 \\
\hline 2 & Preparation & 21862 & 10752 & 2.3 \\
\hline 3 & Imaging process & 21862 & 13440 & 1.9 \\
\hline 4 & Tidying up & 21862 & 10752 & 2.3 \\
\hline 5 & Burning picture / printing images & 21862 & 17920 & 1.5 \\
\hline 6 & Reading the result & 21862 & 5376 & 4.4 \\
\hline 7 & Input data to the system & 21862 & 35840 & 0.9 \\
\hline 8 & Delivering & 20192 & 21504 & 1.2 \\
\hline Workforce requirements & & & 15.4 \\
\hline
\end{tabular}

Source: WISN formula

Based on table 6, indicates the results of the calculation of workforce requirements based on the WISN method show that the proportion of staff needs for inputting patient data is 0.9 personnel, the proportion of staff needed for patient preparation activities is 2.3 personnel, the proportion of staff needs for imaging process activities is 1.9 personnel, the proportion of staff needs for the activity of tidying up the patient and the room as much as 2.3 personnel, the proportion of energy requirements for burning pictures or printing images is 1.5 personnel, the proportion of the need for staff for reading the results is 4.4 personnel, the proportion of the need for staff to do data input activities to the system is 0.9 personnel, and the proportion of need for staff to do delivery is 1.2 personnel.

Based on the calculation of workforce requirements using the WISN method, the total workforce requirement at the radiology unit is 15.4 people, rounded up to 15 people. This number is by the number of workers in the radiology installation of RSU X, which is 15 people.

\section{The ratio of the workforce gap at the radiology department at the RSUX}

The difference between the number of workers required based on the WISN analysis results, and the number of personnel currently in the radiology installation at the RSU X can produce from the WISN ratio.

Table 7. The Ratio of the Workforce Gap in Radiology Installation of RSU X

\begin{tabular}{llllll}
\hline $\begin{array}{c}\text { Existing workforce } \\
\text { (a) }\end{array}$ & $\begin{array}{c}\text { Workforce } \\
\text { requirement }(\mathrm{b})\end{array}$ & $(\mathrm{a}-\mathrm{b})$ & WISN ratio (a/b) & Problem \\
\hline 15 & 15 & 0 & 1.00 & Equal \\
\hline
\end{tabular}

Source: WISN formula

Based on the table 7 calculation table above, it brings out that the workforce gap ratio is comparing the results of the calculation of workforce requirements based on the WISN method with the number of workers in the radiology department at the RSU X. The gap ratio is 1.00 , which means that the number of workers in the radiology department at RSU X is adequate. The interview results represent that the workforce at the radiology department added the workforce recently to have an adequate workforce. 


\section{Discussion \\ Workload Analysis based on Work Sampling}

Based on the research results conducted by observation for seven days at the radiology installation of the RSU X, working time for productive activities was 4383 minutes or $80 \%$, for nonproductive activities were 780 minutes or $14 \%$, and for personal activities was 318 . minutes or $6 \%$ of the total time. The workload is high if the percentage of productive time usage exceeds $80 \%$ of all activity time, the workload is optimum if the time used for productive activities is $80 \%$ of all activity time, and the workload is light if the use of productive time is less than $80 \%$ of the total activity time (Cucu et al., 2019).

Build upon the above calculations, the workload for the radiology department workforce at the RSU X is in the optimum category. It shows the time for the radiology installation workforce's productive activities at the RSU X is $80 \%$ of the total activity time. According to the assumptions of researchers, the workload will affect the work stress experienced by staff. Besides, the workload will also affect workforce performance in the radiology unit at RSU X. This is in line with the research results (Aprilia et al., 2016) at the Ibnu Sina Pekanbaru Islamic Hospital to nurses who stated that workload had a significant effect on performance. The tests carried out showed that the hypothesis, which states that the workload partially has a significant effect on nurses' performance at the Ibnu Sina Pekanbaru Islamic Hospital, is accepted. This is evidenced by count (3.229)> table (2.012) and significance $(0.001)<0.05$.

\section{Workforce Needs Analysis Based on the Workload Method of indicators of staffing needs (WISN)}

Kepmenkes Number 81/MENKES/I/2004 recommended the WISN method to calculate the need for staff. The WISN method is an indicator that shows the amount of workforce needed in a workplace based on workload so that allocation/relocation will be more comfortable and more rational. This method's advantages are easy to operate, easy to use, technically easy to implement, comprehensive and realistic. The WISN method includes five steps: determining available work time, assigning work units and HR categories, compiling workload standards, compiling allowance standards, and calculating the workforce requirements per work unit (Kepmenkes RI, 2004).

\section{Available working hours}

The calculation results are available based on the workload indicators of staffing need (WISN) method for the workforce at the radiology installation at the RSU X of 1792 hours/year or the equivalent of 35 hours/week. According to Article 77, paragraph 1, Law No.13 / 2003 (Erlindai, 2020) is obliged by every employer to implement the provisions of working hours. This working hour provision has been regulated in 2 systems as mentioned above, namely: (a) 7 working hours in 1 day or 40 working hours in 1 week for six working days, or (b) 8 working hours in 1 day or 40 working hours in 1 week for five working days. The two working hours systems give limited working hours, namely 40 (forty) hours in 1 (one) week. If it exceeds the stipulated working hours, the standard working time considers as overtime work so that the workforce is entitled to overtime pay.

Work time available for workers at the radiology unit of the RSU X is following the provisions of Law no. 13/2003, namely not more than 40 hours of work in 1 week (Republik Indonesia, 2003).

\section{Working Unit}

The work units in the RSU X are Inpatient Installation, Outpatient Installation, Emergency Room, Intensive Care Unit, Central Surgical Installation, Laboratory Installation, Midwifery Installation, Nutrition Installation, Medical Rehabilitation Installation, Pharmacy Installation, Radiology Installation, Unit Hemodialysis, Education and Training Installation, Hospital Information System Installation, Hospital Maintenance Installation (IPRS), Laundry Installation, 
Environmental Sanitation, and Hygiene Installation, Medical Record Installation, Body Review Installation, Verification and Health Insurance Installation, and Goods and Services Procurement Installation. In this study, the work unit studied was the radiology installation at the RSU X. The radiology department at the RSU X had digital radiography, CT scan, mammography, and USG.

The radiological equipment at RSU X is complete than the Bina Kasih Medan Hospital, a type B hospital. Bina Kasih Medan Hospital only has radiological equipment, CT scans, and conventional radiographs (Lubis et al., 2020). However, the radiology equipment at the RSU $X$ is not as complete as radiology equipment at the Bahteramas Hospital, Southeast Sulawesi Province. Bahteramas Hospital of Southeast Sulawesi Province is a type B hospital with six radiological equipment, namely CT scan, conventional diagnostic fluoroscopy, mammography, general radiography, interventional fluoroscopy, and mobile radiography (Ntete et al., 2020).

\section{Workload standard}

Based on the results of research conducted at the radiology department at the RSU X, the average time required for each main task is to input patient data for 3 minutes, prepare the patient for 10 minutes, the imaging process for 8 minutes, clean up the patient and the room for 10 minutes. Minutes, burn images/print images for 6 minutes, read the results for 20 minutes, input the results into the system for 3 minutes and send the results to inpatient or outpatient care for 5 minutes.

Following the KepMenKes RI Number 81/Menkes/SK/I/2004 concerning Guidelines for Health Human Resource Planning at Provincial, District/City and Hospital Levels, it states the average time is the time needed to complete the main activity by each HR category in each work unit (Kepmenkes RI, 2004). Sservice standards, standard operating procedures (SOP), available medical facilities and infrastructure, and human resource competencies influencing time requirements to complete activities vary widely. Meanwhile, according to (Alam et al., 2018), the workload standard is obtained by dividing the available work time in one year by the average completion time of each main task.

The standard workload obtained for inputting patient data is 35840 , patient preparation is 10752 , the imaging process is 13440 , cleaning patients and rooms is 10752 , burning images/printing images is 17920 , reading the results is 5376 , inputting the results into the system for 35840 and delivering the outcome to inpatient or outpatient treatment is 21504 . The results of this study are not following the research (Ramadhani et al., 2020), which states that the workload standard for medical record workers at the Ambulu Puskesmas is that the workload standard for making new files is 107508 , file retrieval is 26877 , tracer making is 26877 , file returns amounting to 107508 , preparation of form 53754, checking the completeness of formula sheets of 53754, checking the completeness of the contents of 26.877 , and reporting RM amounting to 17918 . According to the researchers' assumptions, the differences in the standard workload calculations' results are due to differences in the work unit under study, allowing for differences in job descriptions and the average time required to complete each job description.

\section{Allowance standard}

In this study, the allowance factor was workshop and training, incidental meetings, routine meetings, quarterly reports, monthly reports, and daily reports to calculate the allowance standard of 0.3. This study's results are not in line with research (Anggareni et al., 2020), which obtained the calculation of standard allowance at PHC Hospital Surabaya for shift workers of 0.2. This calculation may be different because the allowance factor at the RSU X is different from the allowance factor at the Surabaya PHC Hospital. 


\section{Workforce Requirements Based on WISN}

The study results at the radiology installation at the RSU X show that the workforce requirements at the radiology installation at the RSU X were 15.4 or rounded to 15 people. This result calculated using the WISN method, which divides the quantity of main annual activities by the value of standard workloads and then adds up with allowance standards. The results of calculations in this study are not in line with the research conducted by (Harijanto et al., 2014). It stated that the workforce requirements using the WISN method in HVA Toeloengredjo Hospital's radiology installation were four people. The available working time, standard workloads, and allowance standards for HVA Toeloengredjo Hospital are different from RSU X.

This study's results are also not following the research (Felayani et al., 2013). It stated that based on the calculation of workforce requirements using the WISN method in the Radiology Installation of Budi Rahayu General Hospital of Pekalongan was two people. However, their research only calculated the radiographers' requirements, not the entire workforce in the radiology installation at Budi Rahayu General Hospital of Pekalongan.

According to the researchers' assumptions, the current workforce in the radiology installation at the RSU X follows the workforce requirements based on the WISN method. It is supported by the work sampling method results, indicating that the workload at the radiology installation at the RSU X was in the optimum category. Therefore, no need additional workforce in the radiology installation of RSU X. This study's results are also in line with the research conducted by (Fadila, 2019) in the Filing Unit of Permata Bunda Hospital of Malang. The use of time for productive activities was $82.13 \%$, indicating the heavy workload category. Therefore, it needs to consider the addition of the workforce.

However, the WISN method results cannot be adjusted to the Minister of Health Regulation standards in 2008 (Menteri Kesehatan Republik Indonesia, 2008) because workforce requirements using the WISN method follow the real workload in the field.

\section{Workforce Gap Ratio in the Radiology Installation of the RSU X}

Based on the researchers' calculations, the workforce gap ratio in the radiology installation at the RSU X was currently 1.00. It indicates that the number of workers in the radiology installation at the RSU X was currently adequate. According to the researchers' assumptions, the radiology installation of the RSU X does not require an additional workforce at this time. The workload in the radiology installation of the RSU X also does not cause work fatigue, which triggers work stress and the emergence of conflicts.

It corresponds with research conducted by (Yulaika \& Medtasya Dzykryanka, 2018) that the calculation of the gap ratio of pharmaceutical technical personnel at RSIA KM based on the WISN provisions was 0.49 . it is indicating that the workforce requirement at the time of the study was insufficient. It can result in worker fatigue, which can lead to work stress and conflict. It is essential to have good planning to support quality and excellent services in fulfilling human resource needs. To achieve maximum service at the hospital, planning for workforce requirements based on workload must be carried out (Suryanto, 2020).

Based on the WISN manual, a WISN ratio of 1.00 (one) indicates that the workforce and workloads in an organization balance. In calculating the workforce requirements, it is necessary to consider the management to determine the workforce's need to match the workload performed to increase work productivity and reduce the risk of workforce fatigue (Anggareni et al., 2020). The WISN method's weakness is that the calculation data is a breakdown of real activities, not to project the workforce needed for the future. Therefore, it is necessary to calculate workforce requirements using the WISN method periodically to adjust workforce requirements based on workload (Yulaika \& Medtasya Dzykryanka, 2018). 


\section{CONCLUSION}

The conclusions of this research are use of working time by radiology installation workers at the RSU X for productive activities was $80 \%$; that for non-productive activities was $14 \%$; and that for personal activities was $6 \%$. The workload of the workers in the radiology installation at RSU X was in the optimum category. Calculation of workforce requirements using the WISN method; The working time available in a year at the radiology installation at the RSU X was 107,520 minutes per year. The work unit designated as the research site was the radiology installation at the RSU X. The standard workloads in the radiology installation of the RSU X for inputting patient data were 35840, for patient preparation was 10752 , for imaging process was 13440 , for cleaning up the patient and room was 10752 , for burn/print images were 17920 , for reading the results was 5376 , for input the results to the system was 35840 , and for delivering the results to inpatients or outpatients was 21504 . The allowance standards of the workforce in the radiology installation of the RSU X Hospital was 0.3 The number of workforce requirements in the radiology installation at the RSU X using the WISN method was sufficient, which was 15 people.

The workforce gap ratio at the radiology installation at the RSU X was 1.00 , indicating that the workforce at the radiology installation at the RSU X was currently adequate. The research results showed that the workforce at the radiology installation in October 2020 could counterbalance the existing workload. The WISN ratio can help to assess the implications of a workforce arrangement for improving the service quality. A work unit with a low WISN ratio may reduce service activities to overcome its workload. It has severe implications for the quality of services provided. Health workers in work units with a high WISN ratio should have enough time to provide quality services.

Ffurther research related to Human Resource (HR) planning can use this research as a reference. As input for RSU X leaders in planning recruitment, rotation, and Human Resource (HR) development can use the workload measurements, the estimated number of human resource needs, and development in this research. The application of work sampling in this study is only limited to the use of available work time. Therefore, future research will expect to be able to use the time and motion study method. It knows the use of workload based on working time and knowing the quality of work produced by individuals. Later, an evaluation material in the workforce's planning needs can use it.

\section{REFERENCE}

Acter, T., Uddin, N., Das, J., Akhter, A., Choudhury, T. R., \& Kim, S. (2020). Evolution of severe acute respiratory syndrome coronavirus 2 (SARS-CoV-2) as coronavirus disease 2019 (COVID19) pandemic: A global health emergency. In Science of the Total Environment. https://doi.org/10.1016/j.scitotenv.2020.138996

Alam, S., Raodhah, S., \& Surahmawati, S. (2018). Analisis Kebutuhan Tenaga Kesehatan (Paramedis) Berdasarkan Beban Kerja Dengan Menggunakan Metode Workload Indicator Staffing Needs (WISN) di Poliklinik Ass-Syifah UIN Alauddin Makassar. Al-Sihah: The Public Health Science Journal. https://doi.org/10.24252/as.v10i2.6903

Anggareni, S. R., Ardianto, E. T., Setiawan, D., \& Putra, H. (2020). Analisis Kebutuhan Tenaga Kerja Menggunakan Metode WISN di Rumah Sakit PHC Surabaya. J-REMI : Jurnal Rekam Medik Dan Informasi Kesehatan, 1(3), 155-164.

Aprilia, F., Samsir, S., \& Pramadewi, A. (2016). PENGARUH BEBAN KERJA, STRES KERJA DAN MOTIVASI KERJA TERHADAP KINERJA PERAWAT RUMAH SAKIT ISLAM IBNU SINA PEKANBARU. Jurnal Online Mahasiswa Fakultas Ekonomi Universitas Riau. 
Astuti, R., \& Lesmana, O. P. A. (2018). Pengaruh Motivasi dan Beban Kerja terhadap Kinerja Perawat pada Rumah Sakit Umum Mitra Medika Medan. Jurnal Ilman.

Cucu, Nuraeni, H., \& Muryani, A. (2019). Analisis Beban Kerja Perawat di Ruang Rawat Inap Rumah Sakit Gigi Mulut Universitas Padjadjaran Tahun 2018. Jsk.

Erlindai. (2020). Beban Kerja di Bagian Rekam Medis Menggunakan Metode Workload Indicator Staffing Need di Rumah Sakit Umum Permata Bunda Medan tahun 2019. Excellent Widwifery Journal.

Fadila, R. (2019). Analisis Kebutuhan Sumber Daya Manusia Rekam Medis di Unit Filing. Jurnal Rekam Medis Dan Informasi Kesehatan. https://doi.org/10.31983/jrmik.v2i1.4049

Fadli, F., Safruddin, S., Ahmad, A. S., Sumbara, S., \& Baharuddin, R. (2020). Faktor yang Mempengaruhi Kecemasan pada Tenaga Kesehatan Dalam Upaya Pencegahan Covid-19. JURNAL PENDIDIKAN KEPERAWATAN INDONESIA. https://doi.org/10.17509/jpki.v6i1.24546

Felayani, F., Budiwati, T., Nur Utama, H., \& Budiwati Dosen Program Studi DIII Teknik Rontgen, T. (2013). Analysis of Radiographers Requirements To the Workload in General Radiology Installation Budi Rahayu Pekalongan Hospital. Jurnal Ilmu Dan Teknologi Kesehatan, 1-5.

Harijanto, W., Retriatmadja Moestopo, F., \& Nusaria Nawa Indah, Y. (2014). Penentuan Kebutuhan Tenaga di RS HVA Toeloengredjo dengan Metode Workload Indicators of Staffing Need (WISN) untuk Efisiensi Sumber Daya Manusia. Jurnal Kedokteran Brawijaya. https://doi.org/10.21776/ub.jkb.2014.028.01.21

Hasmawati, H., Kamariah, N., \& Syukur, A. T. (2018). ANALISIS KUALITAS PELAYANAN KESEHATAN DI INSTALASI RADIOLOGI RSUD SYEKH YUSUF KABUPATEN GOWA. Jurnal Administrasi Negara. https://doi.org/10.33509/jan.v24i3.415

Huang, C., Wang, Y., Li, X., Ren, L., Zhao, J., Hu, Y., Zhang, L., Fan, G., Xu, J., Gu, X., Cheng, Z., Yu, T., Xia, J., Wei, Y., Wu, W., Xie, X., Yin, W., Li, H., Liu, M., ... Cao, B. (2020). Clinical features of patients infected with 2019 novel coronavirus in Wuhan, China. The Lancet. https://doi.org/10.1016/S0140-6736(20)30183-5

Kementerian Kesehatan Republik Indonesia. (2020). Situasi Infeksi Emerging. In Kementerian Kesehatan RI.

Kementerian Kesehatan RI. (2020). Keputusan Menteri Kesehatan Republik Indonesia Nomor HK.01.07/MenKes/413/2020 Tentang Pedoman Pencegahan dan Pengendalian Corona Virus Disease 2019 (Covid-19). MenKes/413/2020, 2019, 1-207.

Kepmenkes RI. (2004). Keputusan Menteri Kesehatan RI Nomor 81 tentang Pedoman Penyusunan Perencanaan SDM Kesehatan di tingkat Propinsi, Kabupaten/Kota serta Rumah Sakit. Menteri Kesehatan Republik Indonesia. 
Lubis, H., Manalu, E. D., \& Purba, B. B. (2020). Hubungan Karakteristik Individu dan Kompetensi Dengan Kepatuhan Pemakaian Alat Pelindung diri Pada Tenaga Radiologi Di Rumah Sakit Bina Kasih Medan. Jurnal Inovasi Kesehatan Masyarakat, 1(2), 30-35.

Menteri Kesehatan Republik Indonesia. (2008). Standar Pelayanan Radiologi Diagnostik Di Sarana Pelayanan Kesehatan (p. NOMOR 1014/MENKES/SK/X/2008).

Menteri Ketenagakerjaan, Birokrasi, Menteri Reformasi, \& Negara, M. P. A. (2020). Keputusan Bersama Menteri Agama, Menteri Ketenagakerjaan, Menteri Pendayagunaan Aparatur Negara dan Reformasi Birokrasi Republik Indonesia tentang Perubahan Ketiga atas Keputusan Bersama Nomor 728 Tahun 2019, Nomor 213 Tahun 2019, Nomor 01 Tahun 2019 tent.

Ntete, A., Sabilu, Y., \& Pratiwi, A. D. (2020). Studi Penerapan Manajemen Keselamatan Radiasi Pada Aspek Perizinan Dan Aspek Persyaratan Manajemen Di Instalasi Radiologi Rumah Sakit Umum Daerah Bahteramas Provinsi Sulawesi Tenggara Tahun 2019. Jurnal Kesehatan Dan Keselamatan Kerja Universitas Halu Oleo, 1(1), 20-28.

PDPI. (2020). PNUMONIA COVID-19 : diagnosis dan penatalaksanaan. In Perhimpunan Dokter paru INdonesia.

Permatasari, E. D., \& Pudjirahardjo, W. J. (2015). Kelemahan Workload Indicatorsof Staffing Need Sebagai Metode Perhitungan Jumlah Kebutuhan Tenaga Kesehatan di Puskesmas. Jurnal Administrasi Kesehatan Indonesia. https://doi.org/10.20473/jaki.v3i1.2015.89-98

Ramadhani, R. P., Karimah, R. N., Wibowo, N. S., \& Permana, A. (2020). Analisis Beban Kerja Petugas Rekam Medis Dengan Menggunakan Metode Wisn Dan Fishbone Di Puskesmas Ambulu Tahun 2019. 1(4), 582-593.

Republik Indonesia. (2003). Undang-Undang Republik Indonesia No.13 Tahun 2003 tentang Ketenagakerjaan. Undang-Undang No.13 Tahun 2003, 1, 1-34. http://www.kemenperin.go.id/kompetensi/UU_13_2003.pdf

Rubbiana, N. I. (2015). Analisis Beban Kerja dan Kebutuhan Tenaga Perawat Pelaksana dengan Metode Workload Indicator Staff Need (WISN) di Instalansi Rawat Inap RSUD Kota Bekasi Tahun 2015. In Universitas Islam Negeri Syarif Hidayatullah Jakarta.

Suryanto, H. (2020). Analisis Beban Kerja dan Kebutuhan Sumber Daya Manusia Petugas Rekam Medis Puskesmas Adan-adan Kabupaten Kediri. Jurnal Rekam Medis Dan Informasi Kesehatan, 3(1), 29-35. https://doi.org/10.31983/jrmik.v3i1.5514

WHO. (2010). Workload Indicators of Staffing Need. In World Health Organization.

World Health Organization. (2020). WHO Coronavirus Disease (COVID-19) Dashboard. World Health Organization.

Xie, M., \& Chen, Q. (2020). Insight into 2019 novel coronavirus - An updated interim review and lessons from SARS-CoV and MERS-CoV. In International Journal of Infectious Diseases. https://doi.org/10.1016/j.ijid.2020.03.071 
Ye, F., Xu, S., Rong, Z., Xu, R., Liu, X., Deng, P., Liu, H., \& Xu, X. (2020). Delivery of infection from asymptomatic carriers of COVID-19 in a familial cluster. International Journal of Infectious Diseases. https://doi.org/10.1016/j.ijid.2020.03.042

Yulaika, N., \& Medtasya Dzykryanka, S. (2018). Perencanaan Tenaga Teknis Kefarmasian Berdasarkan Analisis Beban Kerja Menggunakan Metode Wisn Di RSIA KM Pharmacy Technicians Planning Based on Workload Analysis Using WISN Method in RSIA KM. In Jurnal Administrasi Kesehatan Indonesia. 